\title{
US regulation threat over business links...
}

Paul Smaglik, Washington

US clinical researchers and their institutions received a stern warning last week: improve voluntary management of financial conflicts of interest, or face strict federal regulation.

That warning, from Greg Koski, currently professor of anaesthesiology at Massachusetts General Hospital in Boston, provides a preview of how he will run the Office for Human Research Protections (OHRP) when he takes up his new post on 5 September.

Ever since Donna Shalala, secretary of the Department of Health and Human Services, announced last summer that she would place the office, then under the jurisdiction of the National Institutes of Health (NIH), directly under her authority, researchers have been speculating over whether the new supervision would be looser or tighter.

Koski provided some hints at an $\mathrm{NIH}$ conference on financial conflicts of interest. Before his address, at the end of the two-day meeting in Bethesda, Maryland, many researchers had spoken in favour of greater 'guidance' - a euphemism for non-binding policy suggestions.

But Koski hinted that stricter measures might be on the way if this failed to work. "If guidance is not effective, then rules, regulations and laws will follow," he said.

Such measures may already be on the cards. Koski said that conflicts of interest in clinical research have become "pervasive". Physicians routinely get bonuses for encouraging their patients to become research subjects; academic researchers involved with clinical trials are often rewarded with equity in biotech companies; and paid consultancies by pharmaceutical companies to biomedical faculty members are on the rise.

Koski said he would avoid offering specific policy proposals to address those trends until he starts the job. But he sketched out a few ideas. For example, he suggested that universities might need new committees to adjudicate on conflicts of interest, as current institutional review boards (IRBs) could not be the "sole protector" against them.

And while several researchers spoke of the need for clinical scientists, universities and members of IRBs to make their financial interests public, Koski said that such measures are only a starting point. "Disclosure is not enough," he declared.

Several institutions detailed their approaches after being praised at the meeting by Ruth Kirschstein, NIH acting director, for representing 'best practices' in managing conflict of interest. Washington University in St Louis, for example, has strict rules: if a researcher has stock in a company, that company cannot fund the researcher's work.

Johns Hopkins University Medical School in Baltimore, Maryland, has, in addi- tion to an IRB, a conflict-of-interest panel that rules whether a researcher should put stock in a company that has interests in his or her research into escrow, or sell it off.

Both schools also scrutinize their own stock, and examine how their intellectual property could affect the perception of clinical trials. Any intellectual property owned by the university - such as a research tool used to perform an experiment - has to be described in the informed-consent forms that a patient must sign before entering a clinical trial.

Speakers pointed out that the appearance of conflict of interest is as important as evidence of wrongdoing. A perceived conflict of interest dogged James Wilson, director of the University of Pennsylvania Institute of Human Gene Therapy in Philadelphia, after the death of Jesse Gelsinger in a gene-therapy clinical trial last autumn.

Wilson had a large interest in a biotech company that produced viral vectors used for therapeutic gene delivery. Although an outside investigation found no wrongdoing, it concluded that Wilson's holdings caused an appearance of a financial conflict of interest (see Nature 405, 497; 2000). The university ended clinical trials conducted through the institute after the investigation.

Koski says the Pennsylvania incident galvanized interest in research conflicts of interest. Demands are already being heard in Congress, for example, for investigators to be

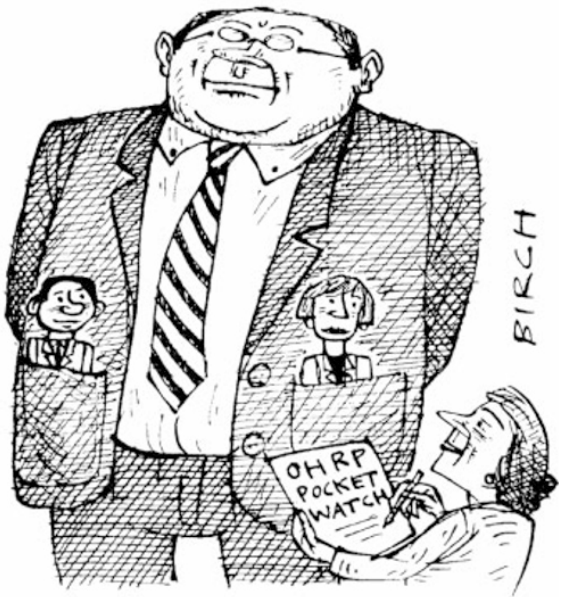

required to give more detailed financial information on informed-consent forms.

Opinions were mixed about the need for more federal regulations governing conflicts of interest. Michele Russell-Einhorn, director of regulatory affairs at OHRP, speaking for a group of scientists who met during the conference to discuss possible ways to manage them, said that "there is a consensus that there should not be regulations".

But Abbey Meyers, president of the National Organization for Rare Disorders, said that patient groups such as her own would like to see more protection against conflicts of interest. Regulation, rather than voluntary compliance, is the best way to ensure this, she said.

\section{... as government seeks more ethics training}

A proposal by the US federal government that all research staff — from managers to research assistants - should be required to take courses in the responsible conduct of research has met with a mixed reaction from organizations representing academic researchers.

Mary J. C. Hendrix, president of the Federation of American Societies for Experimental Biology (FASEB), says that the proposal for mandatory courses on topics such as biomedical ethics and conflict of interest is "overly broad". Last year a report commissioned by the NIH noted that the researchers it funded faced too many regulations (see Nature 398, 180; 1999).

But the Association of American Universities supports broad training in research conduct, Mark Brenner, vice

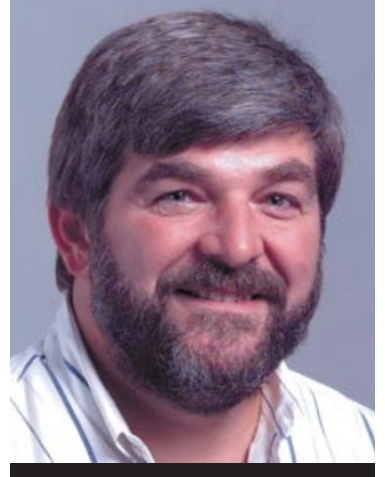

Koski: wants broader impact.

chancellor for research and graduate education at Indiana University told an NIH conference on conflict of interest last week (see above).

The requirements have been proposed by the Department of Health and Human Services' Office of Research Integrity, as a revision of Public Health Service (PHS) guidelines for education in the "responsible conduct of research". FASEB has been pushing to extend the 21 August deadline for responses to the guidelines.

Hendrix agrees that students and trainees should take courses in research conduct, but says requiring everyone operating under a PHS grant to do so would be expensive and timeconsuming.

Greg Koski, incoming director of the Office for Human Research Protections, supports broader training in the ethics of research. "The education needs to go well beyond the investigator," he said during the conference. P. S. http://ori.dhhs.gov/ TheRCRPolicy.htm http://www.faseb.org/opar/ltr/ oriltr.html 